Georgia State University

ScholarWorks @ Georgia State University

\title{
Local Government Cooperation for Joint Provision: The Experiences of Brazil and Spain with Inter-Municipal Consortia
}

Luiz de Mello

OECD, luiz.demello@oecd.org

Santiago Lago-Penas

University of Vigo, slagop@uvigo.es

Follow this and additional works at: https://scholarworks.gsu.edu/icepp

Part of the Economics Commons

\section{Recommended Citation}

Mello, Luiz de and Lago-Penas, Santiago, "Local Government Cooperation for Joint Provision: The Experiences of Brazil and Spain with Inter-Municipal Consortia" (2012). ICEPP Working Papers. 67. https://scholarworks.gsu.edu/icepp/67

This Working Paper is brought to you for free and open access by the International Center for Public Policy at ScholarWorks @ Georgia State University. It has been accepted for inclusion in ICEPP Working Papers by an authorized administrator of ScholarWorks @ Georgia State University. For more information, please contact scholarworks@gsu.edu. 
INTERNATIONAL CENTER FOR PUBLIC POLICY
International Center for Public Policy Working Paper 12-18

March 2012
Local Government Cooperation for Joint Provision: The Experiences of Brazil and Spain with Inter-Municipal Consortia

Luiz de Mello

Santiago Lago-Peñas
GeorgaState University
ANDREWYOUNG SCHOOL

OF POLICYSTUDIES 

International Center for Public Policy

Working Paper 12-18

\section{Local Government Cooperation for Joint Provision: The Experiences of Brazil and Spain with Inter-Municipal Consortia}

\section{Luiz de Mello \\ Santiago Lago-Peñas}

March 2012

International Center for Public Policy

Andrew Young School of Policy Studies

Georgia State University

Atlanta, Georgia 30303

United States of America

Phone: (404) 651-1144

Fax: (404) 651-4449

Email: hseraphin@gsu.edu

Internet: http://aysps.gsu.edu/isp/index.html

Copyright 2006, the Andrew Young School of Policy Studies, Georgia State University. No part of the material protected by this copyright notice may be reproduced or utilized in any form or by any means without prior written permission from the copyright owner. 


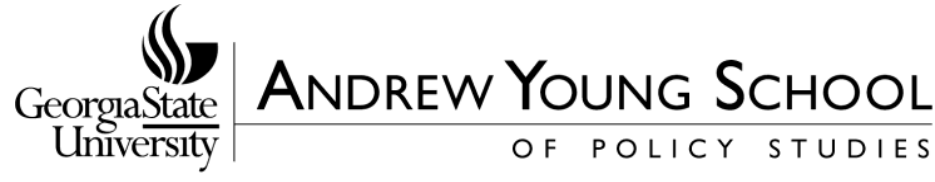

\section{International Center for Public Policy Andrew Young School of Policy Studies}

The Andrew Young School of Policy Studies was established at Georgia State University with the objective of promoting excellence in the design, implementation, and evaluation of public policy. In addition to two academic departments (economics and public administration), the Andrew Young School houses seven leading research centers and policy programs, including the International Center for Public Policy.

The mission of the International Center for Public Policy is to provide academic and professional training, applied research, and technical assistance in support of sound public policy and sustainable economic growth in developing and transitional economies.

The International Center for Public Policy at the Andrew Young School of Policy Studies is recognized worldwide for its efforts in support of economic and public policy reforms through technical assistance and training around the world. This reputation has been built serving a diverse client base, including the World Bank, the U.S. Agency for International Development (USAID), the United Nations Development Programme (UNDP), finance ministries, government organizations, legislative bodies and private sector institutions.

The success of the International Center for Public Policy reflects the breadth and depth of the in-house technical expertise that the International Center for Public Policy can draw upon. The Andrew Young School's faculty are leading experts in economics and public policy and have authored books, published in major academic and technical journals, and have extensive experience in designing and implementing technical assistance and training programs. Andrew Young School faculty have been active in policy reform in over 40 countries around the world. Our technical assistance strategy is not to merely provide technical prescriptions for policy reform, but to engage in a collaborative effort with the host government and donor agency to identify and analyze the issues at hand, arrive at policy solutions and implement reforms.

The International Center for Public Policy specializes in four broad policy areas:

- Fiscal policy, including tax reforms, public expenditure reviews, tax administration reform

- Fiscal decentralization, including fiscal decentralization reforms, design of intergovernmental transfer systems, urban government finance

- Budgeting and fiscal management, including local government budgeting, performancebased budgeting, capital budgeting, multi-year budgeting

- Economic analysis and revenue forecasting, including micro-simulation, time series forecasting,

For more information about our technical assistance activities and training programs, please visit our website at http://aysps.gsu.edu/isp/index.html or contact us by email at hseraphin@gsu.edu. 


\title{
Local Government Cooperation for Joint Provision: The Experiences of Brazil and Spain with Inter-Municipal Consortia
}

\author{
Luiz de Mello* and Santiago Lago-Peñas ${ }^{* * 1}$ \\ OECD Economics Department \\ REDE. IEB, and University of Vigo
}

\begin{abstract}
Local governments often set up inter-municipal consortia to provide public services jointly, rather than individually. The main benefits of joint provision include the potential for improved cost-effectiveness arising from gains from economies of scale and the internalisation of costs and/or benefits of provision, which could otherwise spill over inter-municipal borders and discourage provision. To shed further light on this issue, this paper tests for the presence of scale and spillover effects in local government provision and estimates the determinants of the probability of local government participation in inter-municipal consortia in Brazil and Spain. Empirical evidence suggests that in some cases smaller jurisdictions operate at suboptimal scale and are indeed more likely than their larger counterparts to participate in inter-municipal consortia. In the case of Brazil, governance arrangements between the municipalities and the state governments and/or private-sector providers, but not the federal government, are also associated with a higher probability of participation in inter-municipal consortia, suggesting the presence of "participation spillovers" among governance arrangements.
\end{abstract}

JEL Classification Codes: H72, H77, H75

Keywords: inter-municipal cooperation, local public finance, Brazil, Spain, federalism, probit

Paper prepared for the international conference organized by REDE (www.rede.uvigo.es) on "The Challenge of Local Government Size: Theoretical Perspectives, International Experience and Policy Reform", to take place on 29-30 September 2011 in A Coruña, Spain. The authors are indebted to the conference participants, in particular Germà Bel, Brian Dollery, Ana Herrero, Jorge Martinez-Vazquez, Francisco Pedraja and Francois Vaillancourt, for helpful comments and discussions, but remain solely responsible for any remaining errors and omissions. The opinions and analyses presented in this paper do not necessarily reflect those of the OECD or the Organisation's member or partner countries. Santiago Lago-Peñas acknowledges the financial support of the Spanish Ministry of Science and Innovation (ECO2010-15553). 
Local governments around the world strive to meet residents' demands for goods and services in a cost-effective manner. Where local governments are small, they may be unable to exploit economies of scale in the production and delivery of services. At the same time, if the benefits of local provision spill over inter-jurisdictional borders while provision costs are internalised by local taxpayers, local governments may be discouraged from provision in the first place, which results in an undesirable, suboptimal supply of services. One option for dealing with these difficulties is to consolidate local governments into larger units that would allow for scale effects to be maximised and benefit spillovers to be internalised within the providing jurisdiction. However, consolidations are often difficult to achieve, especially due to political resistance to mergers and amalgamations. Indeed, they may even be undesirable, if they run counter to the objective of bringing the government closer to the people, which usually facilitates social control over government operations and allows for information over local preferences and needs to be extracted more efficiently.

An alternative to consolidation is the establishment of flexible governance structures at the local level that allow for joint provision while maintaining jurisdictional autonomy. This is the case, for example, of the inter-municipal consortia that are currently in place in many countries and allow neighbouring local governments to set up - most often on a voluntary basis - single- or multiple-purpose agencies and/or local enterprises to provide local services to residents of different jurisdictions. The legal and institutional underpinnings of these consortia vary considerably among and sometimes even within countries.

Rather than taking stock of the different arrangements in place around the world, the objective of this paper is to shed light on the determinants of participation in inter-municipal consortia in Brazil and Spain. The cases of Brazil and Spain are instructive for a number of reasons. First, both countries are highly decentralised, and the sub-national governments are at the forefront of service delivery. The local authorities therefore have strong incentives to seek innovative solutions to common problems in an environment of strong support for local self-governance. Second, in both countries the local governments 
(municipalities) have considerable experience with joint provision through inter-municipal consortia. For example, nearly $41 \%$ of Brazil's municipalities with population above 5000 inhabitants participate in such consortia for the provision of health care, and nearly $27 \%$ of Spanish municipalities with population above 5000 inhabitants do so for the provision of social services, including old-age care and support for the disabled, immigrants and ethnic minorities, among other services. Consortia are also in place in Brazil for education, culture, urban development, transport and other services under the purview of local governments. Spanish municipalities also cooperate for the treatment of solid waste collection, waste water treatment and transport. Third, in both countries the municipalities participate in cooperative ventures with higher levels of government and private-sector providers, which provide a wealth of horizontal and vertical governance arrangements for local provision. ${ }^{2}$ To our knowledge, this is the first study in the empirical literature to estimate the drivers of inter-municipal cooperation for the provision of local services in Spain.

We estimate the determinants of unit provision costs for a cross-section of Brazilian and Spanish municipalities, measured as per capita local government spending on a variety of local services, and in turn the drivers of participation in inter-municipal consortia using a probit model that takes into account the endogeneity of unit provision costs. The fact that high unit provision costs may encourage participation in consortia and that participation may drive such costs down would create a reverse causality bias that needs to be addressed in the estimations. Unit provision costs are subject to scale effects and depend on a variety of local government characteristics, such as population density, socio-economic factors and spatial effects.

The main findings of the empirical analysis are as follows.

- The provision of at least some local services exhibit scale and/or spatial spillover effects in both Brazil and Spain. The socio-economic characteristics of local communities, as well as population

2 For simplicity, we use the term inter-municipal consortia to include arrangements for vertical and horizontal cooperation involving municipal governments in both Brazil and Spain. However, in Spanish law the term "consortium" (consorcio) is applied to cooperative ventures between different government tiers (regional and local, or national and local). For inter-municipal (horizontal) cooperation the legal term is "associations" (mancomunidades). See Ferreira (2006) for a survey of the legal basis for inter-municipal cooperation in Spain. Hereinafter we use the term consortium to describe both vertical and horizontal cooperative ventures. 
density, also have a bearing on unit provision costs, a finding that is in line with the empirical literature for these two countries (Solé-Ollé and Bosch, 2005).

- The causal link between unit provision costs and participation in inter-municipal consortia is complex and specific to particular services. High unit provision costs, which suggest that there is scope for enhancing cost-effectiveness, are associated with a higher probability of participation in inter-municipal consortia for the provision of health care and transport in Brazil. In the case of health care, this finding confirms the predictions of a theoretical model developed by Teixeira et al. (2003a and 2003b) and Teixeira (2007). But in some cases, such as urban development in Brazil and solid waste collection in Spain, high unit provision costs actually discourage local governments from participation, while controlling for socio-economic and geographical characteristics that might influence the decision to participate.

- The empirical analysis for Brazil suggests that participation in consortia with higher levels of administration and/or private-sector providers is a powerful predictor of the probability of local government participation in inter-municipal consortia. Instead, governance arrangements involving the federal government appear to substitute for participation in inter-municipal consortia, at least in the case of urban development and health care.

The paper is structured as follows. Section 2 discusses the reasons why local governments may participate in voluntary governance arrangements for the joint provision of local services. Section 3 reviews the Brazilian and Spanish experience with inter-municipal consortia. Section 4 elaborates on the estimating strategy, presents the data and reports the results of the empirical analysis. Section 5 discusses the main findings and highlights their policy implications.

\section{$2 \quad$ Why do local governments cooperate?}

There are many reasons why local governments may want to cooperate in the production and delivery of services under their purview. Country experience suggests that motivation comes primarily from the 
possibility of reducing unit provision costs, which depends in turn on the scope for gains from economies of scale, and for internalising cross-border benefit spillovers within the providing jurisdiction, while at same time preserving local self-government (Norton, 1994; Hulst and van Montfort, 2007).

\section{Maximise economies of scale}

Several services provided by local government are subject to scale effects in production, delivery and use. This is especially the case of vertically integrated (often capital-intensive) services that are in fixed supply, at least in the short run, such as physical infrastructure and urban amenities. Instead, horizontally integrated (often labour-intensive) services, including for example education and health care, use separate production units to produce/deliver the same service. As a result, there is an optimal size at which individual plants can be used efficiently; increases in population and/or land area simply require more production units, which limits the scope for economies of scale.

The presence of scale effects in local government provision implies that, if local government operate at below optimal scale, an increase in size (resident population) would result in lower provision costs in per capita terms until optimality is reached. This creates an incentive for local governments to cooperate among themselves through the joint provision of services, which would allow them to reap the benefits of economies of scale and reduce unit delivery costs.

Despite theoretical intuition, it is not easy to test empirically for the presence of scale effects in local government provision. The public finance literature has favoured the option of gauging the optimal scale of provision by using information available from the actual distribution of the resident population among the various local jurisdictions (Carey et al., 1996). Recent surveys of the literature, such as Byrnes and Dollery (2002), Fox and Gurley (2006), and Martinez-Vazquez and Gomez-Reino (2008), indeed show that scale effects are service-specific and most likely for vertically integrated, capital-intensive services, as suggested by theory. Horizontally integrated, labour-intensive services, such as education, policing, fire protection 
and health care, are less likely to benefit from scale effects as the size of the resident population increases (Ladd, 1992 and 1994). ${ }^{3}$

Scale effects are also present in local government provision in Spain. Solé-Ollé and Bosch (2005) show the existence of scale economies for municipalities with population under 5000 inhabitants using aggregated data for all services. Bel (2006) report empirical evidence in favour of the existence of scale effects for collection, transport and treatment of solid waste in municipalities with population up to 20000 inhabitants (50 000 in some Spanish regions, such as Galicia, according to Bel and Fageda, 2010). ${ }^{4}$

\section{Internalise externality effects}

Local government provision also often generates cross-border externalities. This is the case, for example, when the costs of provision are borne by local taxpayers (residents) while the benefits of a particular service accrue to non-residents. Benefit spillovers are potentially large when beneficiaries are mobile across municipalities, as in the case of recreational and cultural services, and/or when services themselves are mobile, as in the case of fire fighting. Because of such cross-border externalities, local governments may be discouraged from provision in the first place, unless non-residents can be excluded from the service in question and/or local governments reimburse each other for the services delivered to their residents by other jurisdictions. In other words, if services are provided at a level of administration that is unable to internalise the full benefits of provision, the different supplying jurisdictions would play a Nash game that would result in sub-optimal provision. To the extent that sub-optimal provision is sanctioned by the electorate, local governments face an incentive to cooperate among themselves to provide jointly those services that are most likely to generate cross-border externalities.

The presence of cross-border externalities in government provision is usually tested by including spatial effects in expenditure equations (Anselin and Bera, 1998). This procedure can be computationally

See Andrews et al. (2002) for evidence of economies of scale in education for the United States.

4 Moreover, the authors found stronger evidence of scale effects for the municipalities of Galicia than elsewhere, a finding that they attribute to weaker inter-municipal cooperation among the smaller Galician municipalities. 
cumbersome, because it requires the definition of a matrix of jurisdictional weights, based for example on inter-municipal travel distances, from which geographical proximity can be gauged. Alternatively, a less computationally demanding strategy consists of identifying those municipalities in the sample that are located in large urban areas and/or metropolitan regions, where spatial effects are likely to be strongest due to close geographical proximity and high population density. This strategy will be pursued in the estimations reported below, because the samples of Brazilian and Spanish municipalities are large.

In the case of Spain, Solé-Ollé (2001) confirms the existence of cross-borders externalities for urban security, culture and sports, welfare, housing and urban planning in a sample of municipalities of the province of Barcelona. Per capita expenditure in each jurisdiction depends on the level of expenditure in neighbouring jurisdictions. These results have been extended by Solé-Ollé (2006) for a larger sample of Spanish municipalities. Recent results by Bastida et al. (2010) for all Spanish municipalities with over 1000 inhabitants show that there are positive and significant interactions between neighbouring municipalities: the spending of a municipality is positively correlated with its neighbouring municipalities' spending. The empirical findings hold for total municipal expenditure and for six different expenditure categories: solid waste, water supply, housing, civil protection, education and culture.

\section{Other motives}

Local governments may face the incentive to cooperate as a means of securing advantageous conditions in procurement. Governments are large purchasers of goods and services and as a result may influence markets by enjoying monopsony powers. To the extent that suppliers enjoy economies of scale in production, they may also benefit from large purchases and joint procurement by local governments. At the same time, joint provision may allow service providers to gain from the standardisation of services, which improves cost-efficiency. It is nevertheless difficult to measure empirically the scope for cost-efficiency gains in government procurement, and evidence tends to be essentially anecdotal. In particular, it is also difficult to establish whether gains associated with joint procurement is due to better market conditions or economies of scale in procurement and/or supply. 
Inter-municipal cooperation may also allow local governments greater administrative flexibility. This is the case of governance arrangements that offer greater flexibility in personnel management than the often stricter regulations governing public sector employment. Comparative analysis of different governance arrangements is uncommon, but Bel and Fageda (2006) and Bel, Fageda and Mur (2010) find that small Spanish municipalities (with population under 20000 inhabitants) use inter-municipal cooperation as an alternative to privatisation in the cases of solid waste collection and water distribution. While both governance arrangements go in the direction of facilitating the exploitation of economies of scale, small municipalities usually face higher transactions costs than private-sector providers and capacity constraints to deal with private-sector partners, when the service is not produced by the providing municipality. ${ }^{5}$

\section{$3 \quad$ Inter-municipal cooperation in Brazil and Spain}

Brazilian and Spanish municipalities have a fairly long tradition of joint provision and financing through inter-municipal consortia. In both countries, consortia are most often single-purpose entities dedicated to the provision of services and maintenance of urban infrastructure; consortia are seldom established with the primary objective of performing policy coordination and planning tasks. Consortia are usually set up on a voluntary basis, often as non-profit organisations, and the legal/institutional framework for their establishment is provided for by local government legislation. Municipalities also often engage in joint ventures with higher levels of administration, such as the middle-tier jurisdictions (states in Brazil and comunidades autónomas in Spain) and the central government, as well as private-sector providers.

In Brazil, experience with inter-municipal consortia is most developed in the case of health care. Nearly $41 \%$ of the municipalities with population above 5000 inhabitants participated in such consortia in $2009,{ }^{6}$ against just over $16 \%$ in the case of urban planning and development, about $11.5 \%$ in the case of

5 See also Warner (2007) for more discussion.

6 Several consortia were put in place in the 1980s ahead of, and in preparation for, the establishment of a unified national health care system (SUS, Sistema Único de Saúde) and the devolution of responsibility for the provision of health care to the municipalities, which took place gradually in the early to mid-1990s. The decentralisation of health care provision placed a burden on the smaller municipalities, which lacked the scale, the administrative and technical capacity, and the financial means to deliver the range of services to 
education and about $4 \%$ in the case of transport (IBGE, 2009). In Spain, nearly one-half of the municipalities with population above 5000 inhabitants participated in consortia for solid waste collection, against one-third for waste water treatment, some $27 \%$ for the provision of social services, ${ }^{7}$ and about $18 \%$ for transport.

A small but rich literature has emerged about the Brazilian experience with inter-municipal health care consortia. Teixeira et al. (2003a and 2003b) and Teixeira (2007) developed a dynamic two-period game and found that technological parameters, such as scale effects in production and service delivery, as well as the scope for improvements in the quality of services, including through access by residents to a broader array of services, which are rewarded in the electoral process, provide strong incentives for local (elected) policymakers to participate. The probability of participation also depends on local income and preferences, which affect the level of spending on health care and the tax rate needed to finance service delivery, once a consortium is established.

\section{Estimation and main findings}

\section{The estimating strategy and data}

The drivers of local government participation in inter-municipal consortia discussed above - scale effects, cross-border spillovers, geographical and socio-economic conditions, etc. - are also likely to affect unit provision costs directly. The link between unit provision costs and the probability of participation is therefore subject to reverse causality, which would bias the parameter estimates, unless it is addressed appropriately. In particular, high unit provision costs may encourage participation in consortia, and participation may drive such costs down. This hypothesis can be tested by estimating an instrumentalvariable probit model as follows:

be devolved to them, especially in specialised, in-patient care. See Teixeira (2007) for more information on the legal and institutional framework for the establishment of inter-municipal health care consortia.

The social services provided by the Spanish municipalities include general services agreed with the comunidades autónomas, old-age care, home care (SAD), and support for the disabled, immigrants and minorities, amonh other services. See Villalta (2011) and Tranchez (2011) for more information. 


$$
\begin{aligned}
& P_{i}^{*}=\gamma_{0}+\gamma_{1} S_{i}^{k}+\gamma_{2} Z_{i}^{P}+u_{i}, \text { with } \\
& S_{i}^{k}=\beta_{0}+\sum_{j=1}^{n} \beta_{1 j} \phi_{j}\left(N_{i}\right)+\beta_{2} C_{i}+\beta_{3} Z_{i}^{S}+e_{i},
\end{aligned}
$$

where $P_{i}^{*}$ is a latent variable measuring the probability that municipality $i$ participates in an intermunicipal consortium, with $P_{i}=1(=0)$, if $P_{i}^{*} \geq 0(<0) ; S_{i}^{k}$ is per capita local government spending on programme $k$, which proxies for the unit cost of providing the service; $\phi_{j}\left(N_{i}\right)$ is a spline function of the resident population $\left(N_{i}\right)$ of municipality $i$ defining $n+1$ population brackets, which allows for testing for the presence of scale effects in provision; $C_{i}$ is an indicator of local government centrality, which allows for testing for the presence of cross-border spillover effects in provision; $Z_{i}^{P}$ and $Z_{i}^{S}$ are vectors of controls; and $u_{i}$ and $e_{i}$ are error terms, which are assumed to be distributed as $u_{i} \sim(0,1)$ and $e_{i} \sim(0,1)$.

Unit provision costs are proxied by per capita government spending. The main variables of interest are the resident population, which allows for testing for the presence of scale effects in local provision, and an indicator of municipal "centrality" that identifies those municipalities that belong to a metropolitan area to test for the presence of cross-border externalities associated with the provision of municipal services. A piece-wise linear specification is used to test for the presence of scale effects, and the distribution of population among the municipalities is used to set the knots of the spline function at the $25^{\text {th }}, 50^{\text {th }}$ and the $75^{\text {th }}$ percentiles of the distribution. The coefficients of the spline function are defined as changes in slope from the previous population bracket. Negatively signed coefficients suggest the presence of scale effects in municipal provision. As for the centrality indicator, a positive coefficient is indicative of the presence of cross-border externality effects in those municipalities located in large metropolitan areas and urban sprawls.

The set of control variables includes population density and urbanisation. The net effect of population density and urbanisation on unit provision costs depends on the nature of the services provided. In the case of capital-intensive services, unit provision costs may increase in densely populated urban areas due to 
engineering and technical difficulties associated with the construction and upgrading of urban infrastructure and amenities. By contrast, such costs may fall with population density in the case of services whose delivery benefits from agglomeration effects, such as specialised in-patient care and higher levels of education. Relative income is included in the set of covariates to control for socio-economic factors, which affect the demand for local services. Per capita municipal spending is likely to be higher in richer jurisdictions, which can afford to provide a broader and/or more sophisticated array of possibly costlier services demanded by residents. Controls for the ability of local governments to deliver goods and services include the average municipal tax rate and per capita intergovernmental transfers received by the municipalities from higher levels of government.

As for the determinants of participation in inter-governmental consortia, the main variable of interest is the unit cost of municipal provision. In addition, the theoretical literature pioneered by Teixeira et al. (2003a and 2003b) and Teixeira (2007) for Brazilian health care consortia offers some guidance on the choice of control variables. Local preferences and income, which affect the incentives facing municipalities to participate in consortia, are proxied by population density, the urbanisation ratio, the human capital indicator (unemployment rate in the case of Spain) and per capita municipal income relative to the national average. The centrality indicator is included in the regressions to proxy for the incentives for participation arising from the presence of cross-border externalities. The local tax ratio and intergovernmental transfers capture the availability of finance for the delivery of health care, which are also found to affect the incentives facing local policymakers to participate. Dummy variables identifying participation in joint ventures with higher levels of administration and with private-sector providers are also included in the set of controls in the case of Brazil, because they may affect the incentives facing municipalities to establish inter-municipal consortia.

Data are available primarily from Brazilian and Spanish sources, and the variables of interest are defined in Appendix Table 1. 
Table 1. Descriptive statistics ${ }^{1}$

\begin{tabular}{|c|c|c|c|c|}
\hline & Mean & Median & St. dev. & No. obs. \\
\hline & \multicolumn{4}{|c|}{ Brazil } \\
\hline \multicolumn{5}{|l|}{ Spending (per capita, 2000-05 average, $\mathrm{R} \$ 2005$ ) } \\
\hline Total & 616.8 & 555.7 & 312.1 & 4061 \\
\hline Health care/sanitation & 152.9 & 135.7 & 84.3 & 4061 \\
\hline Education/culture & 230.6 & 214.2 & 98.4 & 4061 \\
\hline Administration/planning & 130.3 & 109.8 & 91.8 & 4027 \\
\hline Transport & 36.3 & 22.3 & 42.8 & 4061 \\
\hline Population (thousands, 2000) & 39.4 & 14.5 & 208.0 & 4098 \\
\hline Density (inhabitants per sq. km, 2000) & 122.8 & 28.4 & 608.7 & 4098 \\
\hline Urbanisation ratio $(\%, 2000)$ & 3300.6 & 482.0 & 65780.2 & 4042 \\
\hline Relative income (per capita, \% of national average, 2000) & 100.0 & 88.1 & 60.3 & 4098 \\
\hline Human capital (\% of national average, 2000) & 148.0 & 37.1 & 1075.0 & 4098 \\
\hline Intergovernmental transfers (per capita, 2000-05 average, $\mathrm{R} \$ 2005$ ) & 679.7 & 627.2 & 303.8 & 4061 \\
\hline \multirow[t]{2}{*}{ Average tax rate (per capita, $2000-05$ average, $\mathrm{R} \$ 2005$ ) } & 53.2 & 28.1 & 81.0 & 4061 \\
\hline & \multicolumn{4}{|c|}{ Spain } \\
\hline \multicolumn{5}{|l|}{ Spending (per capita, 2009, current euros) } \\
\hline Total & 1158.2 & 1103.4 & 612.0 & 1296 \\
\hline Waste collection & 47.9 & 32.6 & 55.2 & 1033 \\
\hline Waste water treatment & 82.9 & 67.9 & 165.3 & 1161 \\
\hline Social programmes & 111.0 & 102.4 & 69.0 & 1188 \\
\hline Transport & 12.4 & 5.4 & 20.4 & 474 \\
\hline Population (thousands, 2009) & 31.2 & 11.7 & 115.2 & 1295 \\
\hline Density (inhabitants per sq. km, 2009) & 825.3 & 257.6 & 1877.3 & 1295 \\
\hline Urbanisation ratio $(\%, 2009)$ & 1683.2 & 72.1 & 15069.3 & 1291 \\
\hline Relative income (per capita, \% of national average, 2008) & 100.0 & 81.0 & 83.7 & 1292 \\
\hline Unemployment rate $(\%, 2009)$ & 7.7 & 7.4 & 2.5 & 1292 \\
\hline Intergovernmental transfers (total, per capita, 2009, current euros) & 594.2 & 548.5 & 537.0 & 1298 \\
\hline Average tax rate (per capita, 2009, current euros) & 534.1 & 476.0 & 571.1 & 1298 \\
\hline
\end{tabular}

\section{Baseline results}

Unit delivery costs

The results of the estimations of the first-stage probit regressions, reported in Table 2 for Brazil and

Table 3 for Spain, do not suggest that there are strong scale effects in local government provision in Spain or Brazil when unit provision costs are defined for total municipal expenditure. At a more disaggregated level, however, the relationship between population size and unit provision costs is not uniform across services, at least as far as the experience of Brazil is concerned. There appears to be scale effects in 
administration and planning in Brazil, although the effects do not seem to vary in a statistically discernible manner across population brackets, and transport. In the case of education/culture, unit provision costs rise with population, albeit by a lower proportion in larger jurisdictions, as expected for horizontally integrated services. This is also the case of transport in Spain, where unit delivery costs appear to be higher in larger jurisdictions, reflecting to some extent the fact that urban passenger transport is a compulsory expenditure item in municipalities with population above 50000 inhabitants.

Urban centrality, which proxies for the presence of cross-border externalities in local provision, appears to be associated with higher unit provision costs for transport services in Brazil and Spain, while controlling for population density and other effects that may influence the cost of provision in large urban areas. In the case of health care, unit delivery costs are lower, not higher, in those Brazilian municipalities located in metropolitan areas. This finding could be related to the fact that services are often provided by higher levels of administration, such as the states and the federal government, in addition to the municipalities themselves, in the case of more specialised in-patient care, which tend to be provided in metropolitan areas and larger urban centres. 
Table 2. Expenditure groups: First-stage probit regressions, Brazil ${ }^{1}$ (Dep. Variable: Municipal spending per capita)

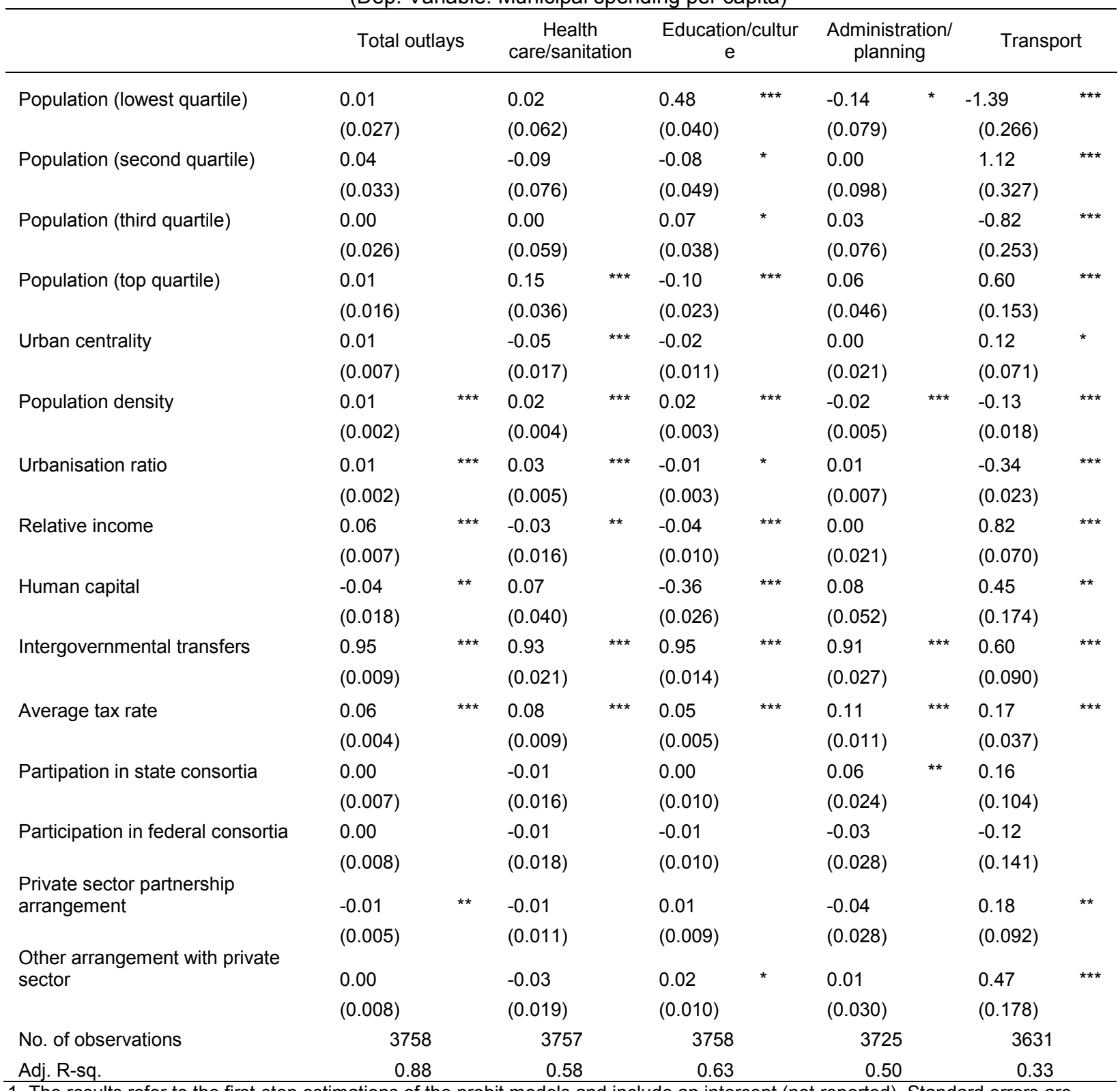

1. The results refer to the first-step estimations of the probit models and include an intercept (not reported). Standard errors are reported in parentheses. All variables are defined in logarithmic form. The sample includes municipalities with population above 5000 inhabitants. Statistical significance at the 1,5 , and 10 percent levels is denoted by respectively $\left(^{* * *}\right),\left({ }^{* *}\right)$ and $\left({ }^{*}\right)$.

Source: Authors' estimations. 
Table 3. Expenditure groups: First-stage probit regressions, Spain ${ }^{1}$ (Dep. Variable: Municipal spending per capita)

\begin{tabular}{|c|c|c|c|c|c|c|c|c|c|c|}
\hline \multirow[b]{2}{*}{ Population (lowest quartile) } & \multicolumn{2}{|c|}{$\begin{array}{c}\text { Total } \\
\text { outlays }\end{array}$} & \multicolumn{2}{|c|}{$\begin{array}{l}\text { Waste } \\
\text { collection }\end{array}$} & \multicolumn{2}{|c|}{$\begin{array}{l}\text { Waste water } \\
\text { treatment }\end{array}$} & \multicolumn{2}{|c|}{$\begin{array}{c}\text { Social } \\
\text { programmes }\end{array}$} & \multicolumn{2}{|c|}{ Transport } \\
\hline & 0.08 & & 0.27 & & -0.19 & & 0.30 & & 2.96 & * \\
\hline & $(0.081)$ & & $(0.360)$ & & $(0.682)$ & & $(0.387)$ & & $(1.788)$ & \\
\hline \multirow[t]{2}{*}{ Population (second quartile) } & 0.02 & & -0.04 & & 0.40 & & -0.49 & & -4.08 & \\
\hline & $(0.119)$ & & $(0.528)$ & & $(1.004)$ & & $(0.567)$ & & $(2.610)$ & \\
\hline \multirow[t]{2}{*}{ Population (third quartile) } & -0.14 & * & -0.01 & & -0.59 & & 0.30 & & 0.97 & \\
\hline & $(0.081)$ & & $(0.354)$ & & $(0.686)$ & & $(0.386)$ & & $(1.542)$ & \\
\hline \multirow[t]{2}{*}{ Population (top quartile) } & 0.07 & & -0.09 & & 0.39 & & -0.14 & & 0.98 & \\
\hline & $(0.045)$ & & $(0.198)$ & & $(0.389)$ & & $(0.217)$ & & $(0.720)$ & \\
\hline \multirow[t]{2}{*}{ Urban centrality } & 0.02 & & 0.01 & & -0.06 & & 0.07 & & 0.70 & ** \\
\hline & $(0.016)$ & & $(0.073)$ & & $(0.141)$ & & $(0.079)$ & & $(0.293)$ & \\
\hline \multirow[t]{2}{*}{ Population density } & 0.01 & & -0.02 & & -0.14 & ** & 0.02 & & -0.21 & * \\
\hline & $(0.007)$ & & $(0.029)$ & & $(0.056)$ & & $(0.032)$ & & $(0.111)$ & \\
\hline \multirow[t]{2}{*}{ Urbanisation ratio } & -0.01 & & 0.08 & *** & 0.06 & & -0.02 & & 0.07 & \\
\hline & $(0.005)$ & & $(0.021)$ & & $(0.040)$ & & $(0.023)$ & & $(0.079)$ & \\
\hline \multirow[t]{2}{*}{ Relative income } & 0.02 & * & -0.03 & & -0.01 & & 0.07 & & 0.11 & \\
\hline & $(0.011)$ & & $(0.051)$ & & $(0.098)$ & & $(0.055)$ & & $(0.204)$ & \\
\hline \multirow[t]{2}{*}{ Unemployment rate } & -0.04 & $* *$ & -0.43 & $* * *$ & 0.02 & & 0.02 & & 0.19 & \\
\hline & $(0.020)$ & & $(0.087)$ & & $(0.165)$ & & $(0.094)$ & & $(0.338)$ & \\
\hline \multirow[t]{2}{*}{ Intergovernmental transfers } & 0.70 & $* * *$ & -0.20 & $* * *$ & -0.04 & & -0.06 & & -0.47 & * \\
\hline & $(0.014)$ & & $(0.065)$ & & $(0.125)$ & & $(0.071)$ & & $(0.267)$ & \\
\hline \multirow[t]{2}{*}{ Average tax rate } & 0.44 & $* * *$ & 0.45 & $* * *$ & 0.27 & ** & 0.24 & $* * *$ & 0.61 & *** \\
\hline & $(0.014)$ & & $(0.059)$ & & $(0.114)$ & & $(0.065)$ & & $(0.215)$ & \\
\hline No. of observations & 1290 & & 1136 & & 1046 & & 1190 & & 39 & \\
\hline Adj. R-sq. & 0.86 & & 0.20 & & 0.01 & & 0.02 & & 0.16 & \\
\hline
\end{tabular}

1. The results refer to the first-step estimations of the probit models and include an intercept (not reported). Standard errors are reported in parentheses. All variables are defined in logarithmic form. The sample includes municipalities with population above 5000 inhabitants. Statistical significance at the 1,5 , and 10 percent levels is denoted by respectively $\left({ }^{* *}\right),\left({ }^{* *}\right)$ and $\left({ }^{*}\right)$.

Source: Authors' estimations.

As for the other covariates, the empirical evidence is mixed for population density, which in Brazil is associated with higher unit provision costs in the case of social spending (education/culture and health care/sanitation) and lower costs in the case of administration/planning and transport. In Spain, unit transport costs are also lower in more densely populated municipalities. Evidence is somewhat mixed for urbanisation, which tends to reduce the unit provision costs of some services in Brazil, such as transport and education/culture, while increasing such costs in the case of health care/sanitation. In Spain, unit provision costs are higher for waste collection in more urbanised jurisdictions. Relative income also matters, and unit provision costs are higher in relatively richer jurisdictions in both Brazil and Spain, while in Brazil the effect varies across services. The effect of affordability is unequivocal in both countries: local 
revenue mobilisation is associated with higher spending per capita, although Brazilian municipalities appear to be more dependent on intergovernmental transfers than their Spanish counterparts.

Data limitations prevent the analysis of whether or not participation in consortia with higher levels of administration and/or with the private sector affects unit delivery costs in Spain. But, as far as the Brazilian experience is concerned, all else equal, participation in consortia with the states appears to increase unit provision costs in the case of administration and planning, and cooperation with private-sector providers tends to increase unit provision costs for both education/culture and transport.

The results are overall fairly robust to re-estimating the regressions for a sample that includes smaller municipalities. There is somewhat stronger evidence in support of the hypothesis of scale effects in local government provision in the case of Brazil if municipalities with less than 5000 inhabitants are included in the sample, but this is not the case of Spain, where the results are robust to the inclusion of smaller municipalities in the sample (with population above 2000 inhabitants). The results for Spain are also fairly robust to restricting the sample to the municipalities of Castilla-La Mancha and Castilla-León, the two autonomous communities where the use of consortia is most widespread and the arrangements for intermunicipal cooperation are more homogenous.

\section{Participation in inter-municipal consortia}

The results of the estimation of the second-stage probit regressions are reported in Table $\mathbf{4}$ for Brazil and in Table 5 for Spain. High unit provision costs are associated with a higher probability of participation in inter-municipal consortia for the provision of health care and transport in Brazil. In other cases, such as education, the probability of participation does not seem to be affected by unit provision costs in Brazil. The unit cost of provision does not seem to provide a strong incentive for participation in Spain, which depends on the level of unemployment and dependence on intergovernmental transfers in nearly all services under examination. Higher-tax Spanish jurisdictions are less likely to participate in consortia, which can be attributed to affordability, which weakens the incentive a jurisdiction may face for joint 
provision. In the case of waste collection, higher unit provision costs seem to reduce, rather than increase, the probability of participation.

In the case of Brazil the probability of local government participation in inter-municipal consortia is strongly affected by participation in consortia with higher tiers of government and/or private-sector providers. Those municipalities that are engaged in cooperative arrangements with the state governments and with private-sector providers are more likely to participate in inter-municipal consortia than those that do not. Instead, governance arrangements involving the federal government appear to substitute for participation in inter-municipal consortia, at least in the case of urban development and health care.

Table 4. Expenditure groups: Second-stage probit regressions, Brazil ${ }^{1}$

(Dep. Variable: Participation in inter-municipal consortia)

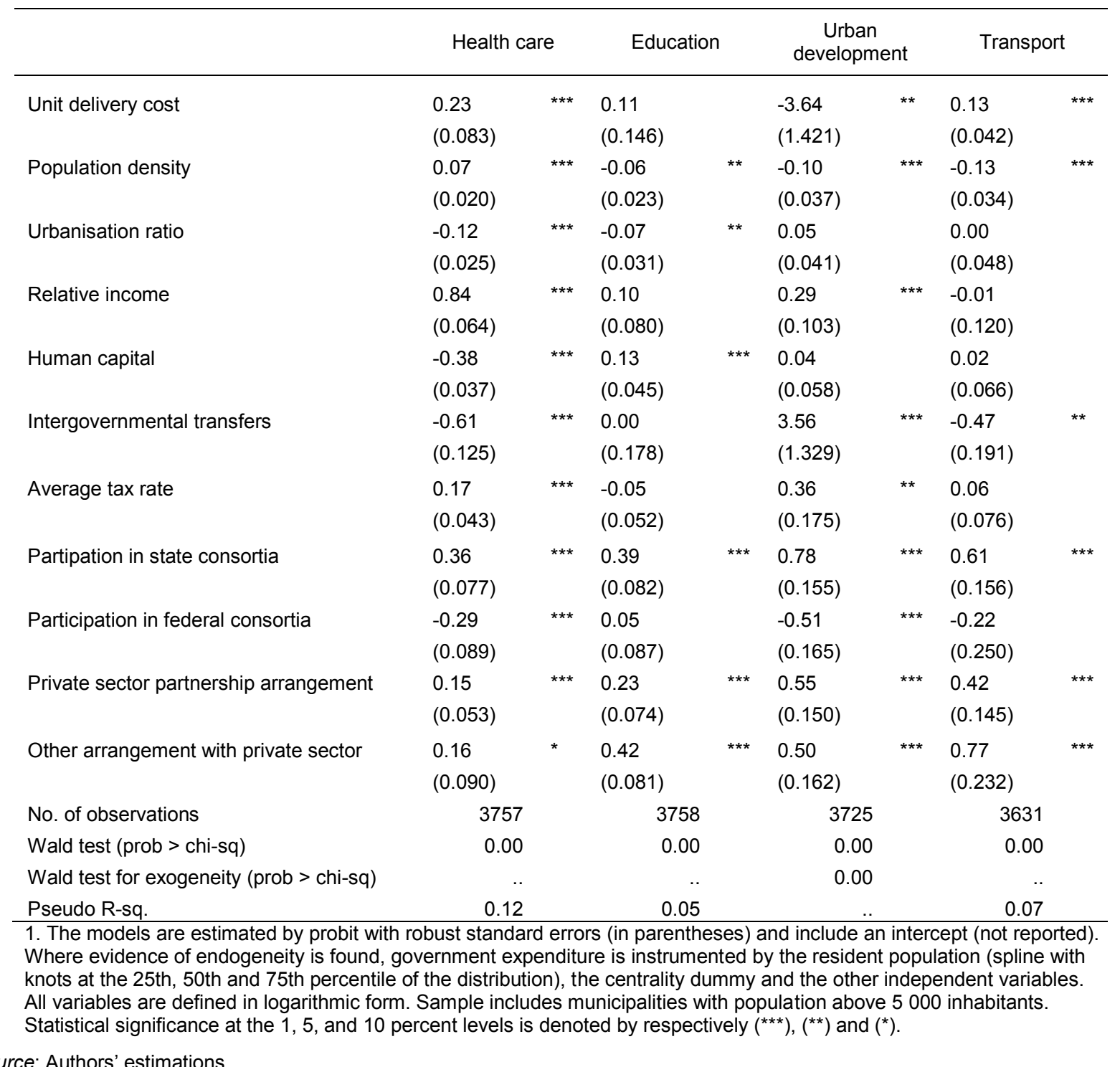

Source: Authors' estimations. 
Table 5. Expenditure groups: Second-stage probit regressions, Spain ${ }^{1}$

(Dep. Variable: Participation in inter-municipal consortia)

\begin{tabular}{|c|c|c|c|c|c|}
\hline & Waste collection & $\begin{array}{l}\text { Waste water } \\
\text { treatment }\end{array}$ & $\begin{array}{l}\text { Social } \\
\text { programmes }\end{array}$ & Transport & \\
\hline \multirow[t]{2}{*}{ Unit delivery cost } & -0.93 & 0.02 & 0.01 & -0.02 & \\
\hline & $(0.312)$ & $(0.027)$ & $(0.043)$ & $(0.039)$ & \\
\hline \multirow[t]{2}{*}{ Population density } & 0.07 & 0.07 & -0.11 & 0.11 & \\
\hline & $(0.046)$ & $(0.044)$ & $(0.042)$ & $(0.082)$ & \\
\hline \multirow[t]{2}{*}{ Urbanisation ratio } & 0.06 & -0.07 & -0.01 & 0.06 & \\
\hline & $(0.044)$ & $(0.035)$ & $(0.033)$ & $(0.062)$ & \\
\hline \multirow[t]{2}{*}{ Relative income } & -0.08 & 0.04 & -0.14 & 0.05 & \\
\hline & $(0.084)$ & $(0.082)$ & $(0.079)$ & $(0.153)$ & \\
\hline \multirow[t]{2}{*}{ Unemployment rate } & 0.01 & 0.98 & 0.59 & 0.90 & *** \\
\hline & $(0.170)$ & $(0.142)$ & $(0.134)$ & $(0.263)$ & \\
\hline \multirow[t]{2}{*}{ Intergovernmental transfers } & 0.01 & 0.30 & 0.25 & 0.42 & * \\
\hline & $(0.131)$ & $(0.109)$ & $(0.104)$ & $(0.214)$ & \\
\hline \multirow[t]{2}{*}{ Average tax rate } & 0.18 & -0.20 & -0.18 & -0.34 & * \\
\hline & $(0.181)$ & $(0.097)$ & $(0.094)$ & $(0.176)$ & \\
\hline No. of observations & 1136 & 1046 & 1190 & 393 & \\
\hline Wald test (prob > chi-sq) & 0.00 & 0.00 & 0.00 & 0.00 & \\
\hline Wald test for exogeneity (prob > chi-sq) & 0.01 & .. & .. & .. & \\
\hline Pseudo R-sq. & & 0.06 & 0.05 & 0.08 & \\
\hline \multicolumn{6}{|c|}{$\begin{array}{l}\text { 1. The results refer to the second-step estimation of the probit models and include an intercept (not reported). Standard } \\
\text { errors are reported in parentheses. Where evidence of endogeneity is found, government expenditure is instrumented by } \\
\text { the resident population (spline with knots at the } 25 \text { th, } 50 \text { th and } 75 \text { th percentile of the distribution), the metropolitan area } \\
\text { dummy and the other independent variables. All variables are defined in logarithmic form. The sample includes } \\
\text { municipalities with population above } 5000 \text { inhabitants. Statistical significance at the } 1,5 \text {, and } 10 \text { percent levels is denoted } \\
\text { by respectively }\left(^{* * *}\right),\left(^{* *}\right) \text { and }\left(^{*}\right) \text {. }\end{array}$} \\
\hline
\end{tabular}


The empirical findings reported above suggest that the provision of at least some local services exhibits scale and spatial spillover effects in both Brazil and Spain. The socio-economic characteristics of local communities, as well as population density, also have a bearing on unit provision costs, a finding that is in line with the empirical literature, and in particular for these two countries (Solé-Ollé and Bosch, 2005). High unit provision costs, which suggest that there is scope for enhancing cost-effectiveness, are associated with a higher probability of participation in inter-municipal consortia for the provision of health care and transport in Brazil. But in some cases, such as urban development in Brazil and waste collection in Spain, high unit provision costs actually discourages local governments from participation, while controlling for socio-economic and geographical characteristics that might influence the decision to participate.

The empirical analysis for Brazil suggests that participation in consortia with higher tiers of government and/or private-sector providers is a powerful predictor of the probability of local government participation in inter-municipal consortia. The probit model results show that the municipalities that are engaged in consortia with the state governments and with private-sector providers are more likely to participate in inter-municipal consortia than those that do not, suggesting that there may be some "participation spillovers", which are not often taken into account in empirical analysis. Instead, governance arrangements involving the federal government appear to substitute for participation in inter-municipal consortia, at least in the case of urban development and health care. This finding indicates that horizontal arrangements among peers may well foster the development of "policy networks" at the local. By contrast, vertical arrangements involving the municipalities and the federal government may curtail the development of inter-municipal consortia.

Data limitations prevented us from testing whether or not vertical governance arrangements affect participation in inter-municipal consortia in Spain. But review of the experience of several European countries by Hulst and van Montfort (2007) is instructive. The authors show that governance arrangements 
comprising local governments and public authorities of higher levels of administration tend to be avoided rather than encouraged in countries such as Belgium, Finland, Germany and the Netherlands. To some extent, this is precisely to prevent involvement of higher levels of government from curtailing the development of bottom-up initiatives that could result in innovative solutions to common challenges. By contrast, mixed arrangements dominate in the United Kingdom and have been encouraged through central government efforts to improve the performance of local government.

These empirical findings reported above suggest that flexible arrangements for the joint provision of local services, such as inter-municipal consortia, may be important tools for local governments to improve the cost-effectiveness of provision while satisfying demands for local autonomy. Joint provision allows local governments to maximise scale effects in production and service delivery, internalise benefit spillovers and seek advantageous conditions in procurement, among other benefits, which are likely to exert downward pressure on unit delivery costs. It is true that such benefits could also potentially arise from the consolidation of local governments into larger units through mergers and amalgamations, for example, but international experience shows that in many cases there is considerable political and public opinion resistance to consolidation (Martinez-Vazquez and Gomez-Reino, 2008). In addition, the benefits of proximity between the government and the citizenry, which has much scope for making the government more responsive to local preferences and needs and for strengthening social control over government operations, would also likely be lost through consolidations. Weighing the benefits and costs of alternative governance arrangements is of course an empirical question, but institutional arrangements change only slowing and the structure of local governments, while far from immutable, are not often amenable to experimentation. ${ }^{8}$

$8 \quad$ For some recent empirical evidence on the benefits and costs of consolidation, see Steiner (2003) for Germany, Sorensen (2006) and Dafflon and Ruegg (2001) for Switzerland. 


\section{REFERENCES}

Afonso, J.R. and L. de Mello (2002), "Brazil: An Evolving Federation”, in E. Ahmad and V. Tanzi (Eds.), Managing Fiscal Decentralization, Routledge, London.

Anselin, L. and A. Bera (1998), "Spatial Dependence in Linear Regression Models with an Introduction to Spatial Econometrics" in A. Ullah and D. Giles (Eds.), Handbook of Applied Economic Statistics, Marcel Dekker, New York, N.Y.

Bastida, F., B. Benito and M.D. Guillamon (2010), "An Assesment of Local Government Spending in Spain", Proceedings of the XVII Encuentro de Economía Pública, Granada, February 2010 (http://www.um.es/dp-hacienda/eep2010/comunicaciones/eep2010-36..pdf).

Bel, G. (2006), "Gasto municipal por el servicio de residuos sólidos urbanos", Revista de Economía Aplicada, Vol. 41, pp. 5-32.

Bel, G. and X. Fageda (2006), "Between Privatization and Intermunicipal Cooperation: Small Municipalities, Scale Economies and Transaction Costs", Urban Public Economic Review, Vol. 6, pp.13-31.

Bel, G. and X. Fageda (2008), "Local Privatization, intermunicipal cooperation, transaction costs and political interests: Evidence from Spain", Research Institute of Applied Economics Working Paper, No. 2008/04, University of Barcelona, Barcelona.

(http://www.ub.edu/irea/working_papers/2008/200804.pdf).

Bel, G. and X. Fageda, (2010), "Empirical analysis of solid management waste costs: Some evidence from Galicia, Spain", Resources, Conservation \& Recycling, Vol. 54, pp. 187-193.

Bel, G., X. Fageda and M. Mur (2010), “¿Por qué se privatizan servicios en los municipios (pequeños)? Evidencia empírica sobre residuos y agua”, Hacienda Pública Española, Vol. 192, pp.33-58. 
Bosch, N. and A. Solé-Ollé, (2005), "On the Relationship between Authority Size and the Costs of Providing Local Services: Lessons for the Design of Intergovernmental Transfers in Spain”, Public Finance Review, Vol. 33, pp. 343-84.

Byrnes J. and B. Dollery (2002), "Do Economies of Scale Exist in Australian Local Government? A Review of the Research Evidence", Urban Policy and Research, Vol. 20, pp. 391-414.

Dafflon, B. and J. Ruegg (2001), Réorganiser les communes, créer l'agglomeration, University of Fribourg, Fribourg, Switzerland.

de Mello, L. (2007), "Fiscal Responsibility Legislation and Fiscal Adjustment: The Case of Brazilian Local Governments", in G.E. Peterson and P.C. Annez (Eds.), Financing Cities, World Bank, Washington, DC.

de Mello, L. (2010), "Europe”, in J. Martinez-Vazquez and P. Smoke (Eds.), The State of Local Government Finance: Are we ready to face the demand?, Second Global Report on Decentralisation and Local Democracy, United Cities and Local Governments, Barcelona.

Ferreira, A.X. (2006), "La Cooperación Municipal en España: Los Entes Supramunicipales en el Ordenamiento Jurídico Español”, Urban Public Economic Review, Vol. 6, pp. 69-88.

Garson, S. (2007), "Regiões Metropolitanas: Obstáculos Institucionais à Cooperação em Políticas Urbanas", Master's thesis, Federal University of Rio de Janeiro, Rio de Janeiro.

Hulst, R. and A. van Montfort (2007), “Intermunicipal Cooperation: A Widespread Phenomenon”, in R. Hulst and A. van Montfort (eds.), Inter-Municipal Cooperation in Europe, Springer.

Ladd, H.F. (1992), "Population Growth, Density and the Costs of Providing Public Services", Urban Studies, Vol. 29, pp. 273-95.

Ladd, H.F. (1994), "Fiscal Impacts of Local Population Growth: A Conceptual and Empirical Analysis", Regional Science and Urban Economics, Vol. 24, pp. 661-86. 
Martinez-Vazquez, J. and J. Gomez-Reino, (2008): “El Tamaño Importa: La Estructura Vertical de Gobierno y la Gestión del Gasto Público Local”, CAF Working Papers, No. 2008/05, Corporación Andina de Fomento, Lima. (http://www.caf.com/attach/19/default/200805Mart\%C3\%ADnezV\%C3\%A1zquezyG\%C3\%B3mez.pdf).

Norton, A. (1994), International Handbook of Local and Regional Government: A comparative Analysis of Advanced Democracies, Edgar Elgar, Aldershot.

Shepherd, W. (1990), The Economics of Industrial Organisation, Prentice-Hall, Englewood Cliffs, N.J.

Slack, E. (2007), "Managing the Coordination of Service Delivery in Metropolitan Cities: the Role of Metropolitan Governance", World Bank Policy Research Working Paper, No. 4317, World Bank, Washington, D.C.

Solé-Ollé, A. (2001), "Determinantes del Gasto Publico Local: ¿Necesidades de Gasto o Capacidad Fiscal?", Revista de Economía Aplicada, Vol. 25, pp.115-56.

Solé-Ollé, A. (2006), "Expenditure Spillovers and Fiscal Interactions: Empirical Evidence from Local Governments in Spain", Journal of Urban Economics, Vol. 59, pp.32-53.

Sorensen, R.J. (2006), "Local Government Consolidations: The Impact of Political Transaction Costs", Public Choice, Vol. 127, pp. 75-95.

Steiner, R. (2003), “The Causes, Spread and Effects of Intermunicipal Cooperation and Municipal Mergers in Switzerland", Public Management Review, Vol. 5, pp. 551-71.

Teixeira, L.S. (2007), Ensaios sobre Consórcios Intermunicipais de Saúde: Funcionamento, Comportamento Estratégico, Incentivos e Economia Politica, Federal Chamber of Deputies, Brasília.

Teixeira, L., M.C. MacDowell and M. Bugarin (2003a), “Consórcios Intermunicipais de Saúde: Uma Análise à Luz da Teoria dos Jogos”, Revista Brasileira de Economia, Vol. 57, pp. 253-81. 
Teixeira, L., M.C. MacDowell and M. Bugarin (2003b), “Economia Política da Formação de Consórcios Intermunicipais de Saúde: Efeitos da Heterogeneidade de Renda e Preferências entre Municípios”, Working Paper, No. 301, University of Brasília, Brasília.

Tránchez, J.M. (2011): “Los Gastos no Obligatorios en los Municípios de Madrid, Cataluña y Andalucía”, Proceedings of the XVIII Encuentro de Economía Pública, Salamanca. (http://www.economiapublica.org/trabajos/4BJose_Manuel_Tranchez.pdf).

Vilalta, M. (Dir) (2011): El Gasto no Obligatorio de los Ayuntamientos Españoles (2004-2007), Federación Española de Municipios y Provincias, Madrid. (http://www.femp.es/files/11-2208-

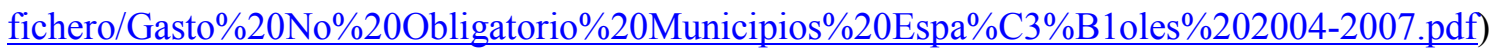

Warner, M. and H. Amir (2003), "Rural-Urban Differences in Privatization: Limits to the Competitive State", Environment and Planning C: Government and Policy, Vol. 21, pp. 703-718.

Warner, M. (2007), "Market-based Governance and the Challenge for Rural Government: U.S. Trends". Social Policy and Administration, Vol. 40, pp. 612-631. 


\section{APPENDIX}

\begin{tabular}{|c|c|}
\hline Variable & Definition and sources \\
\hline Municipal spending per capita & $\begin{array}{l}\text { Per capita spending includes capital and current outlays. For Brazil, expenditure } \\
\text { is disaggregated for transport, education and culture, health care and sanitation, } \\
\text { and administration and planning. Budgetary data (available from IPEA) were first } \\
\text { deflated by the GDP deflator (available from IPEA) and defined in reais of } 2005 . \\
\text { For Spain expenditure is disaggregated for waste collection, waste water } \\
\text { treatment, social programmes and transport. Expenditure data are defined in } \\
\text { current euros and available from the Ministry of Economy and Public Finance. }\end{array}$ \\
\hline Population & Resident population available from IPEA for Brazil and INE for Spain. \\
\hline Population density & $\begin{array}{l}\text { Municipal population divided by the municipality's land area. Available from IPEA } \\
\text { for Brazil and INE for Spain. }\end{array}$ \\
\hline Urbanisation ratio & $\begin{array}{l}\text { Constructed as the ratio (times 100) of the urban to rural residential capital } \\
\text { stocks (available from IPEA for Brazil and from Catastro for Spain } \\
\text { (http://www.catastro.meh.es/esp/estadistica/estadisticas2.asp\#menu1) }\end{array}$ \\
\hline Relative income & $\begin{array}{l}\text { Average income is defined for Brazil as per capita household income (available } \\
\text { from IPEA) in per cent of the national average and for Spain as the per capita } \\
\text { economic activity indicator estimated by La Caixa in per cent of the national } \\
\text { average. ( http://www.anuarieco.lacaixa.comunicacions.com) }\end{array}$ \\
\hline Human capital & $\begin{array}{l}\text { Available for Brazil only and constructed as the ratio of the difference in } \\
\text { expected earnings between educated and non-educated individuals (available } \\
\text { from IPEA) to the national average. }\end{array}$ \\
\hline Unemployment rate & $\begin{array}{l}\text { Registered unemployment over total population expressed in percentage. } \\
\text { Available from La Caixa ( http://www.anuarieco.lacaixa.comunicacions.com) }\end{array}$ \\
\hline Intergovernmental transfers & $\begin{array}{l}\text { For Brazil, intergovernmental transfers received by the municipality (available } \\
\text { from IPEA) are deflated by the GDP deflator and defined in reais of } 2005 \text { and } \\
\text { then divided by the municipal population. For Spain, data are available in current } \\
\text { euros for } 2009 \text { from the Ministry of Economy and Public Finance. }\end{array}$ \\
\hline Average tax rate & $\begin{array}{l}\text { Municipal revenue from tax and non-tax instruments. For Brazil, revenue is } \\
\text { deflated by the GDP deflator (available from IPEA) and defined in reais of } 2005 \\
\text { and then divided by the municipal population (available from IPEA). For Spain, } \\
\text { data are available in current euros for } 2009 \text { from the Ministry of Economy and } \\
\text { Public Finance. }\end{array}$ \\
\hline
\end{tabular}


Urban centrality consortia
Dummy variable taking the value of " 1 " if the municipality is located in a metropolitan area and "0" otherwise. For Brazil, metropolitan areas include the metropolitan regions and urban agglomerations reported by IBGE. For Spain, data on urban areas is provided from AUDES (http://alarcos.esi.uclm.es/per/fruiz/audes/index.htm)

Dummy variable taking the value of "1" if the municipality participates in a consortium, and "0" otherwise. Data for Spain is from the Ministry of territorial organization and public administration (http://ssweb.mpt.es/REL/frontend/inicio/mancomunidades). 